\title{
Optimum of Strategic Asset Allocation for Indonesian Hajj Fund
}

\author{
Beny Witjaksono ${ }^{1^{*}}$, Hamzah ${ }^{2}$ \\ ${ }^{1}$ Esa Unggul University, Indonesia \\ ${ }^{2}$ Pakuan University, Indonesia \\ E-mail: 1benywitjak@yahoo.com, 2hamzah.fe@unpak.ac.id
}

") Corresponding author

JEL Classification:

$\mathrm{C} 44$

C51

C58

C61

D81

E22

E47

Received: March 09, 2021

Revised: April 27, 2021

Accepted: May 07, 2021

\begin{abstract}
Hajj fund must be managed effectively with a diligent approach of standard risk management. This study examines the level of risk management The Hajj Fund Management Agency (BPKH) performs in optimizing its investments: fund and fixed asset portfolios. The measurement data was initially and purposively retrieved. It was later run and processed through linear programming for further analyses. The results indicate that Sharia banking deposits and gold are riskless assets. As far as other asset portfolios, investments are placed strictly based on direct and indirect participation according to the government's regulations to avoid the pressures of market volatility. This study serves as a reference for regulators in formulating appropriate strategic asset allocation to applied related optimized management of hajj fund investment.
\end{abstract}

\section{Keywords:}

optimization of investment, risk and return, strategic assets allocation, BPKH.

How to Cite:

Witjaksono, B., \& Hamzah. (2021). Optimum Strategic of Asset Allocation for Indonesian Hajj Fund. Signifikan: Jurnal Ilmu Ekonomi, 10(2), 195-208. https://doi.org/10.15408/sjie.v10i2.20020. 


\section{Introduction}

Increasing people's economic welfare allows the people to participate in broader social, economic, and religious activities. One of them is the pilgrimage. The pilgrimage requires participants' self-supporting capabilities in physical fitness as well financial sufficiency. Despite long and tedious preparation for the pilgrimage, the number of registrars for pilgrimage each year can exceed the total quota of hajj. For example, the waiting period for selected embarkation can take as long as 39 years. The backlog is due to the number of Hajj registrants exceeds three times the annual Hajj regular quota that is only pegged at 204.000 individuals per year for Indonesia.

The waiting list for pilgrims has resulted in unemployed hajj funds. It is a call for The Hajj Fund Management Agency (BPKH) as a legal fund manager under the Ministry of Religion to manage the accumulated deposits effectively. The growing size of the managed funds can be illustrated from the perspective of the Hajj participants: initial deposit per regular hajj was about IDR 25 million in 2010, then it has increased annually from 2011 to 2018 by $8.17 \%$ per year (Hidayati 2018). Therefore, the accumulated funds need to be managed for future benefits. It is essential to have an Indonesian Hajj Bank (BHI) that focuses explicitly on Shariah-related instruments (Nazri, 2013).

In implementing the preceding, hajj funds investment establish in Indonesia based on law number 13 of the year 2008 articulating the implementation of hajj. The 2008 law triggers law number 34 of 2014 concerning hajj financial management in response to the growing variety of available market instruments. However, differentiating from common investment manager roles, $\mathrm{BPKH}$ as an investment manager of Hajj funds, is strictly regulated by government regulations: PP No.5 of 2018 articles 27, 28, 29, and 30, which only allows Shariah principle-based. The market instruments BPKH can place are Shariah Certificate of Deposits, State Sharia Securities (SBSN) in the form of the Hajj Funds Sukuk (SDHI), Central Government bonds, gold, and other relevant asset management. Three years after issuing preceding regulations, BPKH managed to have its portfolio performances annually yielded to 3 percent (Lisnawati, 2017). Due to the amicable investment performance in 2017, the concerns of securing the future investment yield of Hajj funds against capital market volatility; the Religion Ministry issued law number 23 of 2011 that restricts investment optimization to instruments guided by the corresponding articles stated in PP no 5 of 2018. The minister sees this Hajj savings model in Islamic financial institutions as an alternative contribution to the country's economic development (Shuhaimi, 2011).

One of the challenges that will be faced in doing diversification is a total asset or individual instrument in the capital market. With the number of the instrument, it will be easy to do diversification and reach its purpose. In an emerging market like Indonesia, the amount of stock listed on the Indonesia Stock Exchange is about 570 issuers suitable for the business category, while 366 issuers fulfill the term as Sharia stock. Half of the 366 issuers are the sleep stock or the stock that is rare to be transacted such an investor's choice or manager investor in arranging portfolio is very limited. 
Based on the statement above, the study related to strategic asset allocation optimal for funds that areBPKH manages becomes essential. The purpose is that an investment that $\mathrm{BPKH}$ does can produce a rate of return which optimal and produce the investment's benefit that fulfills two main functions.

The objectives of this research are (1) Mapping and measuring BPKH risk profiles related to investment; (2) Mapping the risks and returns of various financial instruments available for investment; (3) Measuring optimal asset allocation strategies for investment in financial and non-financial instruments that can provide the best risk and return combination for $\mathrm{BPKH}$. This research is expected to consider $\mathrm{BPKH}$ to evaluate performance so that investment and asset allocation in hajj funds management are effective and risk appetite. For BPKH, it is to apply the strategic allocation of an optimized investment fund with various financial instruments according to the combination of the best return risk or a specific target investment. In practical terms, the novelty of this research is to provide an alternative strategy for optimal asset allocation of Hajj funds in Indonesia that has never been studied before by considering risk and return, and effectiveness.

\section{Methods}

This research was done in Hajj Financial Management Agency (BPKH) Jakarta. The time to take the data was done in 2018-2019. The approach method used is the linear programming approach. The data collection technique gets from secondary data. Secondary data is taken from time-series data that is valuable data of various asset groups and also the price of an individual asset. The detail of secondary data that will be used are (1) Index data price including market index and also sectorial index; (2) Data of the individual stock price from all stock price in Indonesia Stock Exchange; (3) Data of commodity price; (4) Available index Sukuk; (5) data of Sukuk price; and (6) Data of issuer financial report in Indonesia Stock Exchange.

The method that used in this research is strategic asset allocation. Perold \& Sharpe (1988) showed four strategies that can be used by the investment manager in setting asset group composition in the portfolio. Those strategies are: (1) Buy and hold; (2) Constant mix; (3) Constant proportion; (4) Option-based portfolio insurance.

Strategic Asset Allocation simulation method, which is used in this research using optimized approach linear programming, in the portfolio with two kinds of asset, the equation (1) can be purpose function where WA and WB are variable which is sought, so $\sigma \mathrm{P} 2$ be on the lowest level. In the notation of linear programming, the equation is:

$\operatorname{Min} \sigma_{\mathrm{P}}^{2}=\sigma_{\mathrm{P}}^{2} \sigma_{\mathrm{P}}^{2}+\sigma_{\mathrm{P}}^{2} \sigma_{\mathrm{P}}^{2}+2 \mathrm{~W}_{\mathrm{A}} \mathrm{W}_{\mathrm{B}} \operatorname{Cov}\left(\mathrm{r}_{\mathrm{A}} \mathrm{r}_{\mathrm{A}}\right)$

Subject to

$$
\begin{gathered}
\mathrm{W}_{\mathrm{A}}+\mathrm{W}_{\mathrm{B}}=1 \\
\mathrm{~W}_{\mathrm{A}}, \mathrm{W}_{\mathrm{B}} \geq 0
\end{gathered}
$$


While strategic asset allocation decides the spread of investment for each group by using the proposed function in equation (3), the aim is to maximize the rate of return.

$$
\max E\left(R_{P}\right)=W_{A} R_{A}+W_{B} R_{B}
$$

Subject to

$$
\begin{gathered}
\mathrm{W}_{\mathrm{A}}+\mathrm{W}_{\mathrm{B}}=1 \\
\mathrm{~W}_{\mathrm{A}}, \mathrm{W}_{\mathrm{B}} \geq 0
\end{gathered}
$$

Simulation from equations (2) and (3) will be applied to do strategic asset allocation, choosing proportion allocation of hajj funds to be invested in the financial instrument such as Sukuk (corporation and government), stocks, and direct investment. Besides that, equations (2) and (3) can be used to do strategic asset allocation sectorial or regional, especially for investment allocation assets on the stock.

\section{Result and Discussion}

\section{Descriptive Statistics}

Strategic Asset Allocation is done first to know risk-return profiles from various available investment assets, and there are Sharia deposit banking, Sukuk, stocks, gold, and direct inclusion. Risk and return profiles from various asset groups can be known by estimating descriptive statistics for each group asset (see Table 1). Based on Table 1, risk profile and the rate of return, sharia deposit banking is categorized as a riskless asset while default sharia banking is still there. However, with the deposit insurance agency (LPS), the probabilities of loss from default risk become low. Table 1 shows that the standard deviation is very high. So, gold cannot be an instrument in short-term investment because of the high volatility of the gold price.

While the performance of sharia-based investment instruments is not significantly different from conventional investment instruments, during the research period, Islamic investment instruments showed slightly better performance (Syafrida et al., 2014). Mockus et al. (2014), the author, provided that the minimal prediction errors do not provide the maximal profits.

Table 1. Profile of Risk-return in Various Investment Instrument

\begin{tabular}{lccccc}
\hline \multicolumn{1}{c}{ Types of Asset } & Average & Std.Deviation & Min & Max & Frequency \\
\hline Sharia Deposit Banking & $6.91 \%$ & $0.31 \%$ & $4.79 \%$ & $10.77 \%$ & Monthly \\
Gold & $7.27 \%$ & $18.55 \%$ & $-20.23 \%$ & $15.64 \%$ & Monthly \\
Total Sukuk & $7.56 \%$ & $6.73 \%$ & $-5.07 \%$ & $5.96 \%$ & Monthly \\
State Sukuk & $7.66 \%$ & $7.13 \%$ & $-5.08 \%$ & $6.28 \%$ & Monthly \\
Corporation Sukuk & $9.33 \%$ & $5.43 \%$ & $-4.58 \%$ & $6.21 \%$ & Monthly \\
Stocks & $12.41 \%$ & $19.09 \%$ & $-17.55 \%$ & $20.06 \%$ & Monthly \\
Rupiah-US Dollar exchange rate & $4.66 \%$ & $10 \%$ & $-9.26 \%$ & $20.58 \%$ & Monthly \\
Direct inclusion & $14.03 \%$ & $8.89 \%$ & $3.78 \%$ & $36.66 \%$ & Quarterly \\
\hline
\end{tabular}

Source: Data processed 
In a company's risk profile, Hudakova \& Dvorsky (2018) said that the biggest risk in a company is market risk, financial risk, and economic risk. $80 \%$ of companies do not invest in manager training for managing risk. The investment should do to for prevention rather than spending costs to finish the problem. Risk management is applied to give the specific direction to solve the company risk. Besides that, Nasr et al. (2019) stated that enterprise risk management (ERM) positively impacts implementation and Tobin's Q ratio to calculate organization work. Belan (2015) said that the management risk process is implementing systematic policy management, starting from the observation until the management of risks. This problem is an important part of management sight according to the function, component, service, and facility.

Next, Preda (2013) said that implementation of managing risk is a difficult thing, the additional value which is getting from the risk management implementation influenced by executive management and its contribution to the system of managing risk in culture risk, process, and experience-related to enterprise risk management (ERM). Shaheen et al. (2020) state that company probability has a positive influence on ERM implementation. Risk management is important; Szaruga (2020) said that the law rule and dynamic change push in the risk management in strategy that is used by the regional government that involves even all units of staff/organization. Because of that, it is needed management risk model that is the maturity to get the satisfaction. Radomska (2014) in management risk implementation needs some aspect that is calculated as an internal process, people or actor, and environment to reach high effectiveness. Related to enterprise risk management, Al-Qaishi \& Al-Batayneh (2018) also said that the theory of risk management is not effective if it is implemented in real conditions, some assumptions are not relevant if it is done in real market conditions, so it is needed deep analysis related how that ERM implementation.

Indonesia Hajj Bank (BHI) can repair the hajj financial management in Indonesia. The optimized strategy of hajj funds management can be done in every aspect. The choosing of investment and cooperation should be able with benefit value that can be reached, do the careful and calculative discussion, and implement Strategic Asset Allocation based on Markowitz to get optimized profit.

\section{Optimized Strategic Asset Allocation for Hajj Funds Management}

Strategic Asset Allocation aims to find out the best combination of investment allocation that can fulfill the purpose of investment from hajj funds management in Indonesia. There are: (a) The purpose of investment to get the lowest total risk portfolio (conservative); (b) The purpose of investment to get the maximum rate of return portfolio (aggressive); (c) The purpose of investment to get equal or higher return rather than average of increasing exchange rate Rupiah to US Dollar (moderate).

Nazri (2013) states that Indonesia Hajj Bank (BHI) can repair hajj financial management in Indonesia as of need analyze the probabilities strategy in optimize hajj funds. Table 1 shows that sharia deposit banking and gold can be categorized as riskless 
assets while left including risky asset category. Optimized simulation is done in three parts that will be done on two conditions. It is a condition without rule limitation and condition with investment limitation on Government Regulation Number 5 the year 2018 about Hajj Financial Management. The research also used some general investment that refers to best practices related to strategic asset allocation, and there are: First, conservative strategy: riskless asset allocation 50\% and Sukuk ratio to stock 1.5. Second, moderate strategy: riskless asset allocation $25 \%$ and Sukuk ratio to stock 1 . Third, moderate strategy: riskless asset allocation $5 \%$ and Sukuk ratio to stock 0.5 .

\section{Strategic Asset Allocation without Direct Inclusion}

Risks in investment activities cannot be eliminated but can be minimized. Therefore, it is needed a strategy and implementation of portfolio management by the investment characteristics in preparing an optimal portfolio to minimize risk (Macenning et al., 2013). Based on the optimized simulation result, strategic asset allocation for hajj funds management in Indonesia shows in Table 2 and Table 3.

Table 2. Return and risk portfolio from strategic asset allocation

\begin{tabular}{lcccccc}
\hline \multirow{2}{*}{ Risk Profile } & \multicolumn{2}{c}{ Purpose 1 } & \multicolumn{2}{c}{ Purpose 2 } & \multicolumn{2}{c}{ Purpose 3 } \\
\cline { 2 - 6 } & $\mathrm{E}(\mathrm{Rp})$ & $\sigma \mathrm{p}$ & $\mathrm{E}(\mathrm{Rp})$ & $\sigma \mathrm{p}$ & $\mathrm{E}(\mathrm{Rp})$ & $\sigma \mathrm{p}$ \\
\hline Conservative & $8.20 \%$ & $3.50 \%$ & $8.39 \%$ & $9.13 \%$ & $9.67 \%$ & $6.75 \%$ \\
Moderate & $9.21 \%$ & $5.59 \%$ & $9.31 \%$ & $7.77 \%$ & $9.83 \%$ & $6.92 \%$ \\
Aggressive & $10.60 \%$ & $7.98 \%$ & $10.62 \%$ & $8.29 \%$ & $10.30 \%$ & $7.49 \%$ \\
\hline
\end{tabular}

Table 3. Allocation of Investment Funds for Each Group (\%)

\begin{tabular}{|c|c|c|c|c|c|c|c|c|c|}
\hline \multirow{2}{*}{$\begin{array}{c}\text { Group } \\
\text { Asset }\end{array}$} & \multicolumn{3}{|c|}{ Purpose 1} & \multicolumn{3}{|c|}{ Purpose 2} & \multicolumn{3}{|c|}{ Purpose 3} \\
\hline & Cons. & Mod. & Agr & Cons. & Mod. & Agr & Cons. & Mod. & Agr \\
\hline Sukuk & 30 & 37.5 & 31.67 & 30 & 37.5 & 31.67 & 42 & 38.67 & 29 \\
\hline Stock & 20 & 37.5 & 63.33 & 20 & 37.5 & 63.33 & 45 & 48.33 & 58 \\
\hline Gold & 0 & 0 & 0 & 50 & 25 & 5 & 3 & 3 & 3 \\
\hline Deposit & 50 & 25 & 5 & 0 & 0 & 0 & 10 & 10 & 10 \\
\hline Total & 100 & 100 & 100 & 100 & 100 & $100 \%$ & $100.00 \%$ & $1000 \%$ & $100 \%$ \\
\hline
\end{tabular}

Syakir (2020) stated that placed instrument and investment in the form of deposit and Sukuk has a chance to increase benefit value through the instrument of capital market and application of tax-saving strategy, allocation strategy of Geld to Maturity, and Available for Sale. From portfolio simulation construction done by Markowitz method 
using Microsoft Excel Solver, there is a benefit value result that is better than the historical data. It is the investment of various instruments and processed weights. So, Hajj Financial Management Agency (BPKH) needs optimum profit. That research is more focused on Strategic Asset Allocation in some kinds of instruments.

Ghofar et al. (2019) said that the hajj fund is much enough (IDR 109.2 trillion), and for each year, it is increasing, and it must be managed by pay attention to the sharia aspect, return, liquidity, risk, and benefit. Hajj funds should not be accumulating and only be utilized by a particular group that can access the banking only, and the benefit should be shared with many people. Strategic Asset Allocation is very useful and has a lot of big benefits. The manager recommended increasing the commitment to common stock to increase the return target.

For purpose 1, the expected rate of return for three strategies there is, for conservative $8.2 \%$, for moderate $9.21 \%$, and aggressive strategy $10.6 \%$. If the purpose of investment changes into purpose 2 (maximum return), the result expectation of return is not far different from the expectation of return portfolio for purpose 1 .

While riskless asset on Purpose 2 is gold, cause gold offers a higher return than risk portfolio on three strategies of Purpose 1. A riskless asset on Purpose 1 is Sharia deposit banking because it has a low volatility value. The market mechanism causes the high volatility of the gold price. The price is made as to the effect of interaction supply and demand in the market. So, Sharia deposit banking is more priority to be chosen as a riskless asset.

Purpose 3 tries to find out optimized allocation asset that results in rate return portfolio minimum equal with the average depreciation of exchange rate Rupiah to US Dollar. It means the target of return that wants to be reached is a minimum of $9.67 \%$, so depreciation exchange rate Rupiah to US Dollar can be pressed. Table 2 shows that a conservative strategy can still result in the rate of return, which is equal to the average depreciation of the exchange rate Rupiah to US Dollar if hajj funds allocated on stock 56.51\% and Sukuk 43.49\%.

Sawitri (2012) states that investment in sharia insurance in Indonesia on the optimal portfolio where mudharaba deposits and Islamic bonds are the most optimal types of insurance for company A. In comparison, the optimal type of insurance for company B is through sharia mutual funds. Natalina (2015) shows that investment strategies in sharia mutual funds are highly dependent on investment managers and can be seen from their investment portfolios. On the other hand, the determination of BPKH's investment portfolio in the future shows that Islamic banking deposits and gold are riskless assets.

Gold and Sharia deposit have the position as riskless assets do not get fund allocation because it is difficult to reach the needed purpose but still must allocate funds on a riskless asset. Suppose a moderate strategy is chosen, which stock being increased to be $47.62 \%$ and Sukuk become 52.38 so the rate of return portfolio result is less high than average of depreciation of exchange rate rupiah to US Dollar. Meanwhile, if an aggressive strategy is chosen, the return portfolio is $10.25 \%$ higher than the average depreciation of 
the exchange rate Rupiah to US Dollar. In comparison, it is not included sharia deposit banking (riskless asset) in the portfolio. The portfolio, which is made from the stock combination and Sukuk still relatively safe because most outstanding Sukuk states Sukuk has low relatively default risk.

\section{Strategic Asset Allocation with Direct Inclusion}

SAA explains anywhere between $80 \%$ and $100 \%$ of long-term fund performance depending on various interpretational subtleties, while active management can be an essential differentiator superposed on asset allocation (EMEA 2013). An optimal portfolio is a portfolio that provides the most significant rate of return with a certain level of risk (Vincent et al., 2019). In this part, direct inclusion on the company is allowed in strategic asset allocations that returns and risks from direct inclusion measure with ROIC size, which shows the company's ability to produce a profit from all operational assets that the company owns. In direct inclusion, financial investment instruments, investoronly face the little business risk.

In doing the simulation with linear programming, the constraint function which is used in this part, are:

Purpose 1 (portfolio with low risk)

First, conservative scenario: total allocation for deposit and gold is $50 \%$, Sukuk's ratio to stock is 1.5 . The total weight of investment is $100 \%$, and the weight for each asset minimum is $0 \%$. Second, moderate: total allocation for deposit and gold is $25 \%$, Sukuk ratio to stock is 1 , the total weight of investment is $100 \%$, and weight for each asset group minimum $0 \%$. Third, aggressive: total allocation for deposit and gold is 5 $\%$, Sukuk ratio to stock is 0.5 , the total weight of investment is $100 \%$, and weight for each asset group minimum $0 \%$

Purpose 2 (portfolio with maximum return):

First, conservative scenario: total allocation for deposit and gold is 50\%, Sukuk's ratio to stock is 1.5 . The total weight of investment is $100 \%$, and weight for each asset group minimum of $0 \%$. Second, moderate scenario: total allocation for deposit and gold is $25 \%$, Sukuk ratio to stock is 1 , the total weight of investment is $100 \%$, and weight for each asset group minimum $0 \%$. Third, aggressive scenario: total allocation for deposit and gold is $5 \%$, Sukuk ratio to stock is 0.5 , the total weight of investment is $100 \%$, and weight for each asset group minimum $0 \%$

Purpose 3 (portfolio with the lowest risk and minimum return equal with an average of Rupiah depreciation):

First, conservative scenario: total allocation for deposit and gold minimum $15 \%$, Sukuk ratio to stock maximum $100 \%$, the total weight of investment is $100 \%$, weight 
for each group of asset minimum $0 \%$, and return of portfolio minimum as the average of depreciation Rupiah plus 0.5 from its standard deviation. Second, moderate scenario: total allocation for deposit and gold minimum $15 \%$, Sukuk ratio to stock maximum $80 \%$, the total weight of investment is $100 \%$, weight for each group of asset minimum $0 \%$, and return of portfolio minimum as the average of depreciation Rupiah plus 0.5 from its standard deviation. Third, aggressive scenario: total allocation for deposit and gold minimum $15 \%$, Sukuk ratio to stock maximum 50\%, the total weight of investment is $100 \%$, weight for each group of asset minimum $0 \%$, and return of portfolio minimum as the average of depreciation Rupiah plus 0.5 from its standard deviation.

Table 4. Return and Risk Portfolio from Strategic Asset Allocation With Direct Inclusion

\begin{tabular}{lllllll}
\hline \multirow{2}{*}{ Risk profile } & \multicolumn{1}{l}{ Purpose 1 } & \multicolumn{3}{c}{ Purpose 2 } & \multicolumn{3}{c}{ Purpose 3 } \\
\cline { 2 - 7 } & $\mathrm{E}(\mathrm{Rp})$ & $\sigma \mathrm{p}$ & $\mathrm{E}(\mathrm{Rp})$ & $\sigma \mathrm{p}$ & $\mathrm{E}(\mathrm{Rp})$ & $\sigma \mathrm{p}$ \\
\hline Conservative & $8.35 \%$ & $1.90 \%$ & $9.58 \%$ & $2.50 \%$ & $9.67 \%$ & $1.87 \%$ \\
Moderate & $9.57 \%$ & $2.38 \%$ & $11.19 \%$ & $4.18 \%$ & $10.68 \%$ & $3.47 \%$ \\
Aggressive & $10.27 \%$ & $3.00 \%$ & $12.48 \%$ & $5.54 \%$ & $12.14 \%$ & $5.05 \%$ \\
\hline
\end{tabular}

The estimation result of strategic asset allocation simulation with direct inclusion shows in Tables 4 and 5. The scenario on strategic asset allocation simulation with direct inclusion is as same as the scenario without direct inclusion. However, some adaptation in deciding optimized limitation did because of limitation has much potency not finding solution of optimized asset allocation as expected.

Based on Table 4 and Table 5, the different purposes will result from a return and risk portfolio rate that has a significant difference. Table 4 shows that investment in direct inclusion has a significant effect on the profile of the risk-return portfolio.

Table 5. Allocation of Investment fund for Each Asset Group (\%)

\begin{tabular}{lccccccccc}
\hline \multirow{2}{*}{ Group } & \multicolumn{3}{c}{ Purpose 1 } & \multicolumn{3}{c}{ Purpose 2 } & \multicolumn{3}{c}{ Purpose 3 } \\
\cline { 2 - 8 } \multicolumn{1}{c}{ Asset } & Cons. & Mod. & Agr & Cons. & Mod. & Agr & Cons. & Mod. & Agr \\
\hline Sukuk & 30 & 37.5 & 47.5 & 10 & 10 & 10 & 10 & 18.75 & 15.83 \\
Stock & 0 & 0 & 0 & 15 & 27.5 & 37.5 & 10 & 18.75 & 31.67 \\
Direct Stock & 20 & 37.5 & 47.5 & 25 & 37.5 & 47.5 & 30.26 & 37.5 & 47.5 \\
Gold & 0 & 0 & 0 & 0 & 0 & 0 & 0 & 0 & 0 \\
Deposit & 50 & 25 & 5 & 50 & 25 & 5 & 50 & 25 & 5 \\
\hline Total & 100 & 100 & 100 & 100 & 100 & 100 & 100 & 100 & 100 \\
\hline
\end{tabular}

Note:

Cons: conservative;

Mod: moderate;

Agr: aggressive 
The interesting finding related to the difference of investment purpose is strategic asset allocation for each purpose. In purpose one, it minimizes the risk portfolio, and the stock does not allocate the investment fund. If it is further observed (see Table 1), it shows that direct inclusion has a risk-return profile that is unique enough. It is that the average rate of return from direct inclusion is higher than other asset groups. However, the risk is higher than other asset groups, but the risk from direct inclusion (standard deviation) is relatively low, especially if compared with the stock as a part of a risky asset. So, in strategic asset allocation with the simulation approach, direct inclusion dominates asset allocation for stock because the risk is lower than the stock. Besides that, the high gold volatility (see table 1) caused this instrument not to allocate investment funds.

In purpose 2, the result aims to get optimized allocation composition that can produce a maximum rate of return. Because of that, purpose two is to add the limitation of fund allocation for Sukuk. It is a minimum of $10 \%$ from the investment fund allocated to Sukuk. Table 5 shows that a combination of stock and direct inclusion can produce a maximum rate of return in various investment strategies. If conservative's strategy which wanted to do and aimed to get the maximum rate of return, so strategic asset allocation is about $10 \%$ for Sukuk, 15\% for stock, 25\% for direct inclusion, and $50 \%$ for sharia deposit banking. If moderate and aggressive are chosen, asset allocation for sharia deposit banking is decreased and distributed evenly on stock and direct inclusion to produce maximum return rate.

For purpose 3, Tables 4 and 5 show information that is quite interest. Using conservative's strategy that minimum allocation for Sukuk is $10 \%$ and for sharia deposit banking is $50 \%$, depreciation rate exchange Rupiah to US Dollar can be closed by return portfolio. The rate of return portfolio by using conservative's strategy is $9.67 \%$, with the risk relatively low, about $1.87 \%$. That strategy allocates investment funds on Sukuk $10 \%$, sharia deposit banking $50 \%$, stock $10 \%$, and direct inclusion $30.26 \%$. The rate of return portfolio will be more increasing when the portion for deposit of sharia banking is decreased and spread out by proportional on Sukuk, stock, and direct inclusion. With moderate and aggressive strategies, depreciation of exchange rate Rupiah to US Dollar can be closed well.

\section{Strategic Asset Allocation According to Government Regulation}

Alternative investments involve specific risks that may be greater than those associated with traditional investments and may be offered only to clients who meet specific suitability requirements, including minimum net worth tests. Investors should consider the special risks with alternative investments, including limited liquidity, tax considerations, incentive fee structures, potentially speculative investment strategies, and different regulatory and reporting requirements (James, 2019). Mubarak \& Fuhaidah (2018) stated that the implementation plan of hajj funds through the BPKH agency is already appropriate with the applicable rule and law. In managing the hajj fund allocation that $\mathrm{BPKH}$ manages, there is government regulation that has related limitations. First, hajj financial placement can be a form of 
sharia banking product, securities, gold, direct investment, and other investment. Second, fund allocation for sharia banking product maximum $50 \%$ for 1-3 after BPKH was held and maximum $30 \%$ after that. Third, the maximum of gold investment is $5 \%$. Fourth, investment in direct inclusion maximum $20 \%$.

Table 6. Return and Risk portfolio from strategic asset allocation with Government Regulation

\begin{tabular}{rcccccc}
\hline \multirow{2}{*}{ Period } & \multicolumn{2}{c}{ Purpose 1 } & \multicolumn{2}{c}{ Purpose 2 } & \multicolumn{2}{c}{ Purpose 3 } \\
\cline { 2 - 7 } & $\mathrm{E}(\mathrm{Rp})$ & $\sigma \mathrm{p}$ & $\mathrm{E}(\mathrm{Rp})$ & $\sigma \mathrm{p}$ & $\mathrm{E}(\mathrm{Rp})$ & $\sigma \mathrm{p}$ \\
\hline 1 - 3 years & $9.23 \%$ & $2.75 \%$ & $10.71 \%$ & $5.84 \%$ & $9.67 \%$ & $3.35 \%$ \\
$>$ 3 years & $9.83 \%$ & $4.59 \%$ & $11.30 \%$ & $7.46 \%$ & $9.67 \%$ & $4.38 \%$ \\
\hline
\end{tabular}

According to those requirements, related regulation with asset allocation limitation of hajj fund using strategy tends to be conservative because of high fund allocation for the riskless asset. Estimating strategic asset allocation simulation results are adjusting with government regulation requirements shows in Tables 6 and 7. In those tables, a strategy which is used is not adjust with the risk profile of hajj fund management because government regulation has given rule related with total hajj fund allocation for sharia deposit banking and gold which is the riskless asset

In Table 7 , if the purpose that to get portfolio by lowest risk, so optimized asset allocation is $13.41 \%$, it is allocated for Sukuk, $15 \%$ allocated for stock, $20 \%$ for direct inclusion, $1.59 \%$ for gold, and the left $50 \%$ for a deposit of sharia banking. With those allocations, the return portfolio rate is $9.23 \%$, with a risk of $2.75 \%$. If compared with strategic asset allocation with direct inclusion like in table 4, the limitation given by the government related to investment allocation does not make the rate of return portfolio and its risk worse than if it does not use government requirements. If the allocation is to achieve purpose 2, the allocation for deposit of sharia banking reduces from $50 \%$ to $30 \%$, which fund allocation for deposit of sharia banking transfer for Sukuk $(23.10 \%)$ or stock $(25 \%)$ so it can produce the rate of return portfolio $9.83 \%$ and risk $4.59 \%$.

Table 7. Optimized Asset Allocation with limitation of Government Regulation

\begin{tabular}{lcccccc}
\hline \multicolumn{1}{c}{ Group } & \multicolumn{2}{c}{ Purpose 1 } & \multicolumn{2}{c}{ Purpose 2 } & \multicolumn{2}{c}{ Purpose 3 } \\
\hline \multicolumn{1}{c}{ Asset } & $1-3$ years & $>$ 3 years & $1-3$ years & $>$ 3 years & $1-3$ years & $>$ 3 years \\
\hline Sukuk & $13.41 \%$ & $23.10 \%$ & $10.00 \%$ & $10.00 \%$ & $7.35 \%$ & $25.83 \%$ \\
Stock & $15.00 \%$ & $25.00 \%$ & $40.00 \%$ & $50.00 \%$ & $22.38 \%$ & $22.33 \%$ \\
Direct & $20.00 \%$ & $20.00 \%$ & $20.00 \%$ & $20.00 \%$ & $20.00 \%$ & $20.00 \%$ \\
Gold & $1.59 \%$ & $1.90 \%$ & $0.00 \%$ & $5.00 \%$ & $0.27 \%$ & $1.84 \%$ \\
Deposit & $50.00 \%$ & $30.00 \%$ & $30.00 \%$ & $15.00 \%$ & $50.00 \%$ & $30.00 \%$ \\
\hline Total & $100 \%$ & $100 \%$ & $100 \%$ & $100 \%$ & $100 \%$ & $100 \%$ \\
\hline
\end{tabular}


If we are using purpose 2 , it allocated the asset to get maximum the rate of return portfolio, so the period 1-3 years after $\mathrm{BPKH}$ was held, the allocation for deposit of sharia banking reduces to be $30 \%$ from before, $50 \%$. In comparison, fund allocation for Sukuk is $10 \%$, stock $40 \%$, and direct inclusion $20 \%$. With those compositions, the return portfolio rate is $10.71 \%$, with a risk of $5.84 \%$. Profile of risk-return is competitive enough, especially if it compared with the result of simulation without government requirement. However, in purpose 2, hajj fund allocation for deposit of sharia banking should not reach maximum allocation it is $50 \%$ in the first of $1-3$ years and $30 \%$ after that. That thing is done so the rate of return that got become maximal.

Meanwhile, to reach purpose 3, it has to function the rate of return portfolio as hedging of depreciation exchange rate Rupiah to US Dollar, optimized of asset allocation with government requirements still can be effective to reach purpose 3 . In the first three years from BPKH was held, fund allocation for Sukuk is $7.35 \%$, stock $22.38 \%$, direct inclusion $20 \%$, gold $0.27 \%$, and deposit of sharia banking is $50 \%$. With those compositions, the rate of return portfolio can be the same with average depreciation exchange rate Rupiah to US Dollar, but with risk relatively low, it is 3.35\%. Furthermore, after the third year, BPKH was held, the allocation for sharia banking reduces to be maximum of $30 \%$, the allocation for Sukuk to be $25.83 \%$, stock $22.33 \%$, direct inclusion $20 \%$, and gold $1.84 \%$. With those compositions, the rate of return that got the same as the depreciation exchange rate Rupiah to US Dollar with higher risk (4.38\%) was the effect of decreasing fund allocation for deposit of sharia banking. So, the government's requirements related to the limitation of hajj fund investment allocation do not make the rate of return portfolio less competitive if hajj fund allocation for other instruments (Sukuk, stock, and direct inclusion) can be optimized.

\section{Conclusion}

Analysis result of Strategic Asset allocation on aspect without direct inclusion is chosen as a moderate strategy. The results showed that the analysis result to risk-return profile from various investment assets is known to deposit sharia banking and gold as a riskless asset. The stock increase is $47.62 \%$ and Sukuk to be $52.38 \%$, so the rate of return portfolio produced is less high average depreciation exchange rate rupiah to US Dollar.

In aspect with direct inclusion, in purpose 1, direct inclusion dominated asset allocation for stock because the risk that has is lowest than stock. In purpose two, if conservative's strategy wanted to be done and aims to get maximum the rate of return, strategic asset allocation is $10 \%$ for Sukuk, $15 \%$ for stock, $25 \%$ for direct inclusion, and $50 \%$ for Sukuk a deposit of sharia banking. In purpose 3, using conservative's strategy that minimum allocation for Sukuk is $10 \%$ and for deposit of sharia banking is $50 \%$, depreciation value of exchange rate Rupiah to US Dollar can be closed by return portfolio.

In the aspect of Strategic Asset Allocation based on government regulation, if purpose two that used, so the time period 1-3 years after BPKH was held, the allocation for deposit of sharia banking can be reduced to be $30 \%$ from its before $50 \%$. For the 
purpose 3, which function the rate of return portfolio as hedging of depreciation exchange rate Rupiah to US Dollar. BPKH has a unique positive asset flow strength of around IDR $10-12 \mathrm{~T}$ per year plus an average net return value of $6-7 \%$. This condition allows $\mathrm{BPKH}$ to carry out an aggressive investment strategy if there is a correction in the Sukuk market, and vice versa, an active profit-taking strategy if the market is in a positive trend.

Based on the result of the research, it is suggested that: First, for BPKH, it is hoped to apply the strategic allocation of an optimized investment fund with the various financial instruments according to the combination of the best return-risk or based on the best return-risk specific target investment which is stated before. Second, for the next researcher, it is hoped to study better strategic, applied, optimized management of hajj fund investment, which is customized with market conditions that tend more fluctuating related to the limitation that $\mathrm{BPKH}$ has.

\section{References}

Al-Qaishi, K. M., \& Al-Batayneh, R. M. (2018). Risk Factors in Financial Services Industry: Application, Threats, Theoritical and Empirical Literature in Management of Risk. International Journal of Economics and Financial Issues, 8(2), 210-218.

Belan, L. (2015). Implementation of Risk Management in the Armed Forced of The Slovak Republic. Journal of Defense Resource Management, 6(2), 103-108.

EMEA. (2013). Strategic Asset Allocation. Multi-asset Solutions Research Papers, 6, 1-22.

Ghofar, A., Firdaus, A., \& Rulindo, R. (2019). Pemilihan Alternatif Investasi Dana Haji dalam Mendorong Pertumbuhan Ekonomi: Pendekatan Analytic Network Process. Journal of Finance and Islamic Banking, 2(2), 183-204.

Hidayati, A. (2018). Fluktuasi Biaya Haji Dalam Rupiah, Dolar AS dan Dinar: Perspektif Investasi Syariah. Muslim Heritage, 3(1), 139-156.

Hudakova, M., \& Dvorsky, J. (2018). Assessing the Risks and Their Sources in Dependence on The Rate of Implementing the Risk Management Process in the SMEs. Equilibrium, 13(3), 543-567.

James, R. (2019). Strategic Asset Allocation Models. Investment Strategy Quarterly, 10, 22-23

Lisnawati. (2017). Optimalisasi Pengelolaan Dana Haji Melalui Investasi. Buletin APBN, $17(2), 3-7$.

Macenning, A. R. A. D., Hakim, D. B., \& Andati, T. (2019). Analysis and Optimization of Investment Portfolio Performance: Case Study of PLN Pension Fund. International Journal of Research and Review, 6(12), 481-488.

Mockus, J., Katin, I., \& Katina, J. (2014). On the Optimalization of Investment Strategies in The Context of Virtual Financial Market by The Individual Approach to Risk. Informatica, 25(2), 241-264.

Mubarak, M. A., \& Fuhaidah, U. (2018). Manajemen Pengelolaan Dana Haji Republik Indonesia (Studi Kolaborasi antar Lembaga BPKH, KEMENAG, dan Mitra Keuangan dalam Pengelolaan Dana Haji). Iltizam Journal of Shariah Economic Research, 2(2), 67-88. 
Nasr, A. K., Alaei, S., Bakhshi, F., Rasoulyan, F., Tayaran, H., \& Farahi, M. (2019). How Enterprise Risk Management (ERM) Can Effect on Short-term and Long-term Firm Performance: Evidence from the Iranian Banking System. Entrepreneurship and Sustainability Center, 7(2), 1387-1403.

Natalina, S. A. (2015). Analisa Manajemen Portofolio Investasi Reksadana Syari'ah Ditinjau dari Strategi Investasi Berdasakan Resiko Investasi dan Pengukuran Kinerja. Realita, 13(2), 189-199.

Nazri, R. (2013). Bank Haji Indonesia: Optimalisasi Pengelolaan Dana Haji untuk Kesejahteraan Jamaah Haji Indonesia (Sebuah Gagasan). Jurnal khazanah, 6(1), 13-26.

Perold, A. F., \& Sharpe, W. F. (1988). Dynamic Strategies for Asset Allocation. Financial Analysis Journal, 44(1), 16-27.

Preda, C. (2013). Implementing a Risk Management Standard. Journal of Defense Resource Management, 4(1), 111-120.

Radomska, J. (2014). Operational Risk Associated With the Strategy Implementation. Management, 18(2): 31-43.

Sawitri, A. N. (2011). Analisis Investasi dalam Asuransi Syariah di Indonesia Terhadap Portofolio Optimal. Media Ekonomi, 19(2), 30-51

Shaheen, R., Aga, M., Rjoub, H., Abualrub, A. (2020). Investigation of the Pillars of Sustainability Risk Management as an Extension of Enterprise Risk Management on Palestinian Insurance Firms Profitability. Sustainability, 12(4709), 1-20.

Shuhaimi, M. (2011). Tabung Haji as an Islamic Financial Institution for Sustainable Economic Development. Proceeding of $2^{\text {nd }}$ International Conference on Humanities, Historical, and Social Sciences, 17, 236-240.

Syafrida, I., Aminah I., \& Waluyo, B. (2014). Perbandingan Kinerja Instrumen Investasi Berbasis Syariah dengan Konvensional pada Pasar Modal di Indonesia. Al Iqtishad: Journal of Islamic Economics, 6(2), 195-206

Syakir, A. T. (2020). Optimalisasi Imbal Hasil Badan Pengelola Keuangan Haji dengan Alokasi Aset Strategis. (Unpublished Thesis). Bandung: SBM ITB.

Szaruga, B. D. (2020). Maturity of Risk Management Culture. Enterpreneurship and Sustainability Issues, 7(3), 2060-2078.

Vincent, I., Anggraeni, L., \& Andati, T. (2019). Optimization of Investment Portfolio Performance: Case Study of PT Asuransi Jiwa Taspen. International Journal of Research and Review, 6(8), 256-265. 